\title{
Sinergi Bela Negara dan Kemanusiaan dalam Kegiatan Pengabdian Kepada Masyarakat Prodi Teknik Mesin Unhan RI di RSIA Melania Cibinong
}

\author{
Linus Yoseph Wawan Rukmono ${ }^{1}$, Arie Sukma Jaya ${ }^{2 *}$ \\ Program Studi Teknik Mesin, Universitas Pertahanan, Sentul, Jawa Barat \\ Email: ${ }^{1}$ linus.rukmono@idu.ac.id, ${ }^{2 *}$ arie.jaya@idu.ac.id
}

(Naskah masuk: 30 Maret 2021, direvisi: 19 April 2021, diterima: 20 Mei 2021)

\begin{abstract}
Abstrak
Kewajiban utama masyarakat akademis di lingkungan Program Studi (Prodi) Teknik Mesin Universitas Pertahanan Republik Indonesia (Unhan RI) adalah melaksanakan Tri Dharma Perguruan Tinggi, yang salah satu komponennya adalah Pengabdian Kepada Masyarakat (PKM). Berada di dalam kelembagaan Kementerian Pertahanan, masyarakat akademis di lingkungan Unhan RI ditekankan untuk menjadi cendekiawan Bela Negara. Oleh karena itu, Prodi Teknik Mesin Unhan RI merancang kegiatan PKM yang tidak hanya bertujuan untuk menerapkan keahlian Teknik Mesin bagi masyarakat umum tetapi juga menyebarluaskan semangat Bela Negara. Puncak dari setiap kegiatan PKM tersebut adalah pelaksanaan sosialisasi Bela Negara dalam rangka memberikan kesadaran pelaksanaan Bela Negara melalui profesi masing-masing. Artikel ini membahas terwujudnya sinergi Bela Negara dan Kemanusiaan melalui kegiatan PKM Prodi Teknik Mesin Unhan RI di Rumah Sakit Ibu dan Anak (RSIA) Melania Cibinong. Tahap pertama kegiatan PKM ini adalah penerapan keahlian Teknik Mesin melalui perbaikan berbagai peralatan pendukung operasional rumah sakit seperti komputer, genset dan alat RO (Reverse Osmosis). Selanjutnya, tahap kedua PKM ini adalah kegiatan sosialisasi Bela Negara pada pimpinan dan karyawan rumah sakit. Melalui kegiatan PKM ini, semangat Bela Negara masyarakat akademis di lingkungan Teknik Mesin Unhan RI terwujud melalui penerapan keahliannya dalam mendukung keberlangsungan pelayanan kemanusiaan terhadap masyarakat. Di lain pihak, pimpinan dan karyawan RSIA Melania Cibinong memiliki kesadaran bahwa Bela Negara dapat diwujudkan melalui tanggung jawab profesinya dibidang pelayanan kemanusiaan. Pemilihan institusi kesehatan sebagai tempat dilaksanakannya PKM Prodi Teknik Mesin Unhan RI menjadi contoh sinergi antara semangat Bela Negara dan Kemanusiaan yang mendukung kehidupan berbangsa dan bernegara yang sehat dan humanis.
\end{abstract}

Kata Kunci: teknik mesin, sinergi, bela negara, kesehatan, kemanusiaan.

\section{The synergy of Bela Negara and Humanity in Community Service of the Mechanical Engineering Study Program Unhan RI at RSIA Melania Cibinong}

\begin{abstract}
The main responsibility of the academic community of the Mechanical Engineering Study Program (Prodi Teknik Mesin) of the Republic of Indonesia Defense University (Unhan RI) is the implementation of the Tri Dharma of Higher Education, one of which is Community Service (PKM). Within the Ministry of Defense institution, the academic community of Unhan RI is always emphasized to become intellectuals of Bela Negara (the spirit of defending the country). Therefore, the Prodi Teknik Mesin Unhan RI designed PKM activities that not only aim to apply Mechanical Engineering expertise to the community but also spread the spirit of Bela Negara. The culmination of each PKM activity was the implementation of Bela Negara socialization to provide awareness of the implementation of Bela Negara through their own professions. This article discusses the realization of the synergy of Bela Negara and Humanity through PKM activities by Prodi Teknik Mesin Unhan RI at Mother and Child Hospital (RSIA) Melania Cibinong. The first phase of this PKM activity was the application of Mechanical Engineering expertise through the reparation of hospital operational support equipments such as computers, generator set, and RO (Reverse Osmosis) devices.
\end{abstract}


Next, the second stage of this PKM was the socialization of Bela Negara to leaders and employees of the hospital. Through this PKM activity, the spirit of Bela Negara of the Prodi Teknik Mesin Unhan RI academic community was actualized through the implementation of their expertise to support the continuity of humanitarian services to the community. On the other side, the leaders and employees of RSIA Melania Cibinong had an awareness that Bela Negara can be applied through the responsibility of their profession in the field of humanitarian services. The selection of a health institution as a place for PKM by the Prodi Teknik Mesin Unhan RI was an example of the synergy between the spirit of Bela Negara and Humanity that supports a healthy and humanist life of the nation and state.

Keywords: mechanical engineering, synergy, Bela Negara, health, humanity.

\section{PENDAHULUAN}

Universitas Pertahanan Indonesia Republik Indonesia (Unhan RI) merupakan lembaga pendidikan tinggi yang diselenggarakan oleh pemerintah [1]. Unhan RI secara akademik dibina oleh Kementerian Pendidikan dan Kebudayaan dan secara fungsional dibina oleh Kementerian Pertahanan [2]. Unhan RI merupakan kampus yang menekankan pentingnya Bela Negara bagi masyarakat akademis di lingkungannya [3, 4]. Program studi (Prodi) Teknik Mesin Unhan RI merupakan bagian dari Fakultas Teknik Militer Unhan RI [5]. Prodi Teknik Mesin Unhan RI mendukung visi dan misi Unhan RI untuk mencetak lulusan Sarjana Teknik dibidang Teknik Mesin yang memiliki karakteristik bela negara dan memahami ilmu pertahanan. Oleh karena itu, lingkungan pendidikan Teknik Mesin Unhan RI disesuaikan untuk mencetak kader intelektual bela negara yang menguasai desain, produksi, material, konversi energi, serta mekatronika permesinan untuk pertahanan. Sebagai institusi pendidikan, maka Prodi Teknik Mesin Unhan RI perlu melakukan Tri Dharma Perguruan Tinggi yang salah satunya adalah Pengabdian Kepada Masyarakat (PKM).

Institusi Rumah Sakit Ibu dan Anak (RSIA) Melania Cibinong merupakan rumah sakit Kelas C yang berada di Cibinong, Bogor. RSIA Melania Cibinong memiliki beberapa pelayanan diantaranya perawatan umum, UGD, perawatan anak (pediatrik), laboratorium, radiologi (x-ray), serta perawatan kehamilan dan wanita (obstetri dan gynaecologi) [68]. Mengingat lokasinya yang strategis dengan jumlah pelayanan yang cukup tinggi dan pentingnya pelayanan rumah sakit ini bagi kehadiran kehidupan baru yang sehat, maka keberlangsungan operasional rumah sakit ini menjadi penting. Oleh karena itu, program PKM Prodi Teknik Mesin Unhan RI dilakukan pada institusi kesehatan ini.

Pemilihan institusi kesehatan sebagai tempat dilaksanakannya PKM bermaksud untuk memperoleh pengalaman sinergi semangat Bela Negara dan Kemanusiaan. Penerapan keahlian Teknik Mesin pada institusi kesehatan diharapkan dapat mendukung operasional institusi tersebut sehingga selalu menghasilkan pelayanan yang prima. Sinergi dalam PKM ini diharapkan dapat menjadi percontohan bagi bidang ilmu yang lain untuk semakin meningkatkan kolaborasi dalam mewujudkan masyarakat Indonesia yang sejahtera. Selain itu, sinergi ini juga diharapkan dapat menambah luas penerapan keahlian Teknik Mesin, tidak hanya dalam ranah konvensional yang terkait industri dan rekayasa teknik, tetapi juga ranah yang berkaitan dengan kemanusiaan dan kesehatan.

\section{METODE KEGIATAN}

Prodi Teknik Mesin Unhan RI melakukan PKM di RSIA Melania Cibinong dengan dua bagian utama yaitu kegiatan penerapan keahlian Teknik Mesin dalam perbaikan dan perawatan alat-alat mekanis dan kegiatan sosialisasi Bela Negara. Kegiatan ini menjadi pelaksanaan Tri Dharma perguruan tinggi yang dilakukan para dosen dari Prodi Teknik Mesin Unhan RI. Pihak-pihak yang terlibat dalam kegiatan ini antara lain:

a. Teknik Mesin Unhan RI: Pimpinan Program Studi, para dosen, laboran dan staf tata usaha prodi.

b. RSIA Melania Cibinong: Pengurus yayasan, suster rumah sakit dan staf rumah sakit.

A. Kegiatan penerapan keahlian Teknik Mesin

Penerapan keahlian Teknik Mesin pada kegiatan PKM di RSIA Melania Cibinong dilakukan melalui beberapa aktivitas antara lain:

1. Perbaikan komputer

Komputer merupakan salah satu hasil teknologi yang memudahkan aktivitas manusia. Pada zaman ini, pengenalan akan komputer dapat meningkatkan taraf hidup manusia $[9,10]$. Pengenalan tersebut dapat dilakukan melalui pelatihan perawatan ataupun perbaikan komputer [11]. Pada operasional rumah sakit, seperti RSIA Melania Cibinong, komputer merupakan salah satu komponen pendukung yang vital. Namun demikian, karena usia pemakaian komputer yang digunakan di RSIA Melania Cibinong sudah cukup lama, sehingga sering mengalami kendala tidak responsif (hang). Oleh karena itu, perlu dilakukan perawatan pada bagian perangkat keras dan install ulang beberapa perangkat lunak untuk mengatasi kendala lambatnya kerja komputer. Selain itu, perlu dilakukan juga penambahan Random Access Memory (RAM) pada beberapa komputer yang digunakan untuk pendataan pasien.

Kegiatan perbaikan komputer ini penting untuk mendukung kelancaran kegiatan administrasi dan digitalisasi pendataan/rekam medis pasien. Kegiatan ini dilakukan secara paralel selama dua minggu pada empat komputer untuk tetap menjaga keberlangsungan operasional pendataan pasien. Gambar 1 menunjukkan salah satu bagian perangkat keras dari komputer yang diperbaiki pada kegiatan ini. 


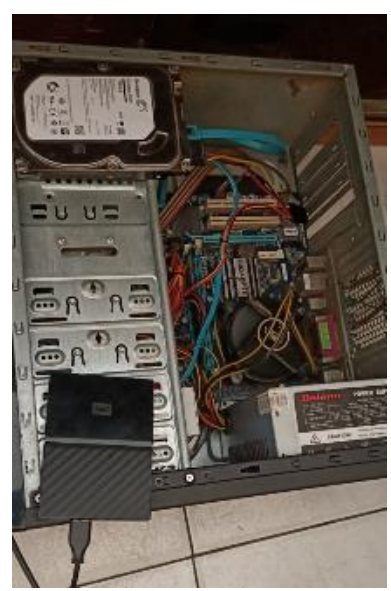

Gambar 1. Perangkat Keras Komputer yang Diperbaiki

2. Perbaikan dan pelatihan perawatan mesin generator set (genset)

Genset merupakan salah satu mesin yang dibutuhkan membangkitkan arus listrik pada saat terjadinya pemadaman arus listrik [12, 13]. Genset RSIA Melania Cibinong, seperti pada Gambar 2, menggunakan bahan bakar solar dan listrik yang dihasilkan dapat digunakan untuk beberapa keperluan penting seperti menjaga keberlangsungan instrumen elektronik pada ruang bersalin dan penerangan rumah sakit. Namun demikian, genset ini mengalami kerusakan sejak tahun 2011 karena kurangnya perawatan dan tidak adanya tenaga ahli yang dapat memperbaikinya. Oleh karena pentingnya fungsi mesin ini, maka perbaikan genset dimasukkan dalam program PKM. Alokasi waktu untuk kegiatan perbaikan ini adalah lima minggu mulai dari tahap analisis kebutuhan peralatan dan tenaga kerja, pelaksanaan perbaikan sampai dengan persiapan metode perawatan. Perawatan dengan metode yang tepat sangat penting untuk menjaga keberlangsungan operasional genset $[14,15]$. Oleh karena itu, pada kegiatan PKM ini juga dilakukan pelatihan perawatan genset kepada karyawan rumah sakit yang bertugas sebagai operator dari genset tersebut.

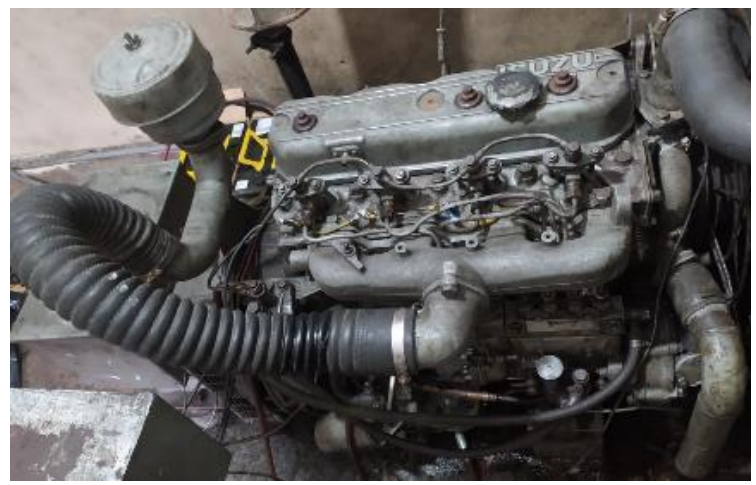

Gambar 2. Mesin Genset RSIA Melania Cibinong
3. Perbaikan alat pemurni air Reverse Osmosis (RO)

Reverse Osmosis (RO) merupakan metode yang diterapkan secara efektif pada alat pemurni air. Untuk kebutuhan sehari-hari, masyarakat umumnya memperoleh air dari beberapa sumber seperti sumur, ledeng, ataupun sumber air alami. Namun demikian, air yang diperoleh secara langsung dari sumber tersebut memiliki kontaminan dalam kadar yang cukup tinggi sehingga belum layak digunakan sebagai air minum. Dengan metode RO pada alat penjernih air, maka kontaminan yang membuat air memiliki bau, warna, atau rasa yang tidak sedap dapat disaring, sehingga air yang keluar dari alat tersebut dapat dikonsumsi sebagai air minum $[16,17]$.

Untuk skala industri, metode RO dapat secara efektif menyaring bakteri dan virus dalam air dengan membran yang memiliki ukuran pori mencapai 0,001 mikron [18].

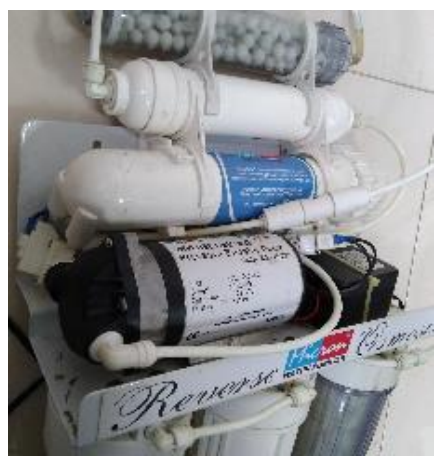

Gambar 3. Alat RO pemurni air yang tidak berfungsi

Alat RO pemurni air di RSIA Melania Cibinong seperti pada Gambar 3 merupakan jenis alat untuk skala pemakaian sedang. Kendala yang dihadapi adalah alat tersebut tidak berfungsi dengan baik karena pompa tidak menyala. Oleh karena pentingnya alat tersebut untuk operasional RSIA Melania Cibinong, maka perbaikan pemurni air ini dimasukkan dalam program PKM. Alokasi waktu untuk kegiatan perbaikan ini adalah tiga minggu mulai dari tahap analisis permasalahan, pelaksanaan perbaikan sampai dengan persiapan metode perawatan.

4. Pembuatan alat cuci tangan otomatis

Mencuci tangan merupakan salah satu komponen dari Gerakan 3M yang disosialisasikan untuk mencegah penyebaran virus COVID19 [19, 20]. Sebagai bagian dari pengabdian masyarakat, maka Prodi Teknik Mesin Unhan RI mengupayakan tersedianya sarana cuci tangan yang efektif dan efisien serta nyaman bagi penggunanya. Oleh karena itu, dilakukan produksi terhadap mesin cuci tangan otomatis dengan sensor gerak inframerah yang telah dirancang pada kajian sebelumnya dengan berbasis karakteristik antropometri [21]. Alokasi waktu untuk kegiatan pembuatan ini adalah empat minggu mulai dari tahap pembuatan, pengiriman dan uji coba 
Tabel 1. Jadwal pelaksanaan PKM

\begin{tabular}{|c|l|c|c|c|c|c|c|c|c|}
\hline \multirow{2}{*}{ No. } & \multicolumn{2}{|c|}{ Kegiatan } & \multicolumn{3}{c|}{ Januari 2021 } & \multicolumn{4}{c|}{ Februari 2021 } \\
\cline { 3 - 9 } & & I & II & III & IV & I & II & III & IV \\
\hline 1 & Persiapan program PKM & & & & & & & & \\
\hline 2 & Perbaikan komputer & & & & & & & & \\
\hline 3 & $\begin{array}{l}\text { Perbaikan dan pelatihan } \\
\text { perawatan genset }\end{array}$ & & & & & & & & \\
\hline 4 & Perbaikan alat $R O$ & & & & & & & \\
\hline 5 & $\begin{array}{l}\text { Pembuatan alat cuci tangan } \\
\text { otomatis }\end{array}$ & & & & & & & & \\
\hline 6 & Sosialisasi Bela Negara & & & & & & & & \\
\hline 7 & Pembuatan laporan program & & & & & & & & \\
\hline
\end{tabular}

produk. Dengan adanya mesin cuci tangan otomatis di lingkungan RSIA Melania Cibinong, diharapkan meningkatkan kesadaran karyawan dan pengunjung rumah sakit untuk tetap menjaga kebersihan dan mengurangi potensi penyebaran virus COVID19.

\section{B. Sosialisasi Bela Negara}

Sosialisasi Bela Negara dilakukan untuk memberi wawasan bela negara melalui profesi dan kompetensi personal maupun lembaga masing-masing. Kegiatan ini juga diharapkan mampu membangkitkan motivasi dan semangat berkarya pada bidangnya masing-masing sebagai tindakan bela negara dalam kehidupan berbangsa dan bernegara. Materi sosialisasi antara lain Dasar Negara Pancasila, Wawasan Nusantara, Bhinneka Tunggal Ika dan UUD 1945. Sosialisasi ini disampaikan dengan bahasa yang mudah dicerna dan menarik bagi para karyawan rumah sakit yang sebagian besar berlatar belakang SMA. Kegiatan ini merupakan puncak dari rangkaian PKM yang dilakukan oleh Prodi Teknik Mesin Unhan RI. Alokasi waktu untuk sosialisasi ini adalah dua jam yang dilangsungkan bersamaan dengan acara penutupan kegiatan pengabdian masyarakat di RSIA Melania Cibinong.

\section{Jadwal PKM}

Kegiatan PKM Prodi Teknik Mesin Unhan RI dilaksanakan dalam rentang waktu dua bulan mulai dari Januari 2021 sampai dengan Februari 2021. Jadwal pelaksanaan kegiatan PKM tersebut dapat dilihat pada Tabel 1. Seperti dapat dilihat pada tabel, kegiatan ini diawali dengan tahap persiapan program sebagai koordinasi awal antara Prodi Teknik Mesin Unhan RI dengan RSIA Melania Cibinong. Program penerapan keahlian Teknik Mesin dimulai setelah tahap persiapan, sesuai dengan alokasi waktu yang ditetapkan sebelumnya. Puncak acara dari program ini adalah program sosialisasi Bela Negara yang dilakukan setelah berhasilnya pelaksanaan tahap penerapan keahlian. Program ini diakhiri dengan pembuatan laporan kegiatan.

\section{PELAKSANAAN KEGIATAN}

Kegiatan PKM Prodi Teknik Mesin Unhan RI telah dilaksanakan di RSIA Melania Cibinong. Rangkaian kegiatan PKM diawali dengan berbagai kegiatan penerapan keahlian
Teknik Mesin karena permasalahan lapangan yang diselesaikan pada kegiatan ini memerlukan waktu yang lebih panjang. Kegiatan penerapan pertama yaitu dengan melakukan perbaikan komputer seperti pada Gambar 4. Gambar tersebut menunjukkan aktivitas perbaikan komputer yang dilakukan oleh dosen Prodi Teknik Mesin Unhan RI. Komputer dapat diperbaiki sesuai dengan jangka waktu yang ditentukan. Permasalahan komputer yang kurang responsif telah diatasi dan komputer dapat beroperasi untuk pendataan pasien kembali dengan lebih baik.

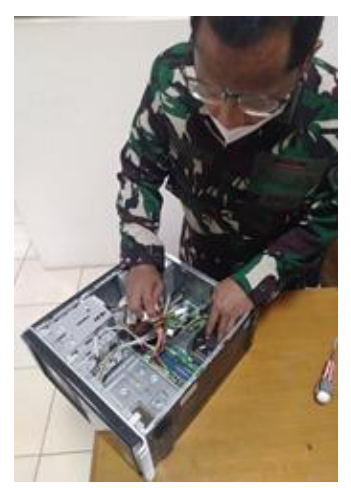

Gambar 4. Aktivitas perbaikan komputer
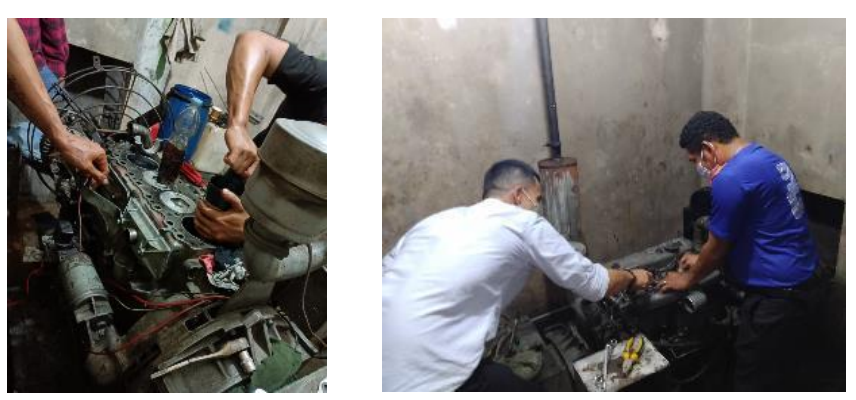

Gambar 5. Aktivitas perbaikan genset

Kegiatan penerapan keahlian Teknik Mesin selanjutnya adalah perbaikan genset, seperti yang dapat dilihat pada Gambar 5. Gambar tersebut menunjukkan genset yang sedang diperbaiki oleh dosen dan teknisi Prodi Teknik Mesin Unhan RI. Perbaikan genset ini merupakan aktivitas yang memerlukan waktu paling lama dan sumber daya manusia yang paling banyak. Meskipun komponen utama mesin masih 
dalam keadaan baik, pembiaran kerusakan yang terlalu lama memerlukan penggantian beberapa komponen, terutama pada bagian sambungan listrik, daerah pembakaran dan sumber daya pemantik. Tingkat kompleksitas mesin juga memerlukan tenaga teknisi yang berpengalaman supaya tidak menyebabkan kerusakan yang lebih parah. Namun demikian, genset telah berhasil diperbaiki dan dapat beroperasi kembali sebagai pembangkit listrik dalam keadaan pemadaman arus listrik.

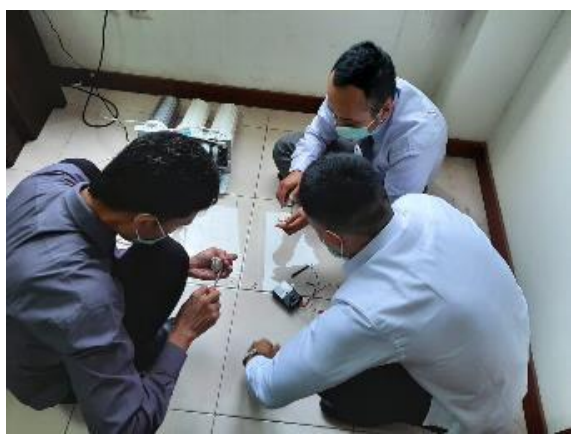

(a)

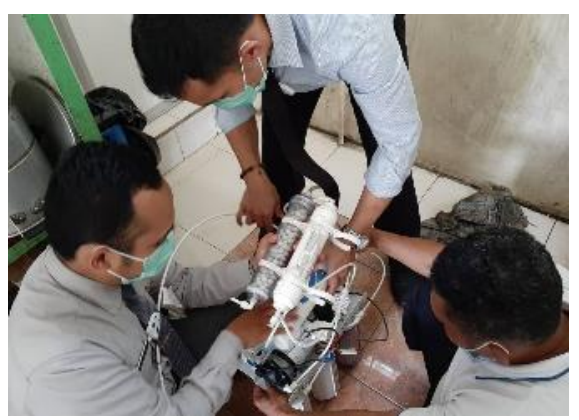

(b)

Gambar 6. Aktivitas perbaikan pemurni air metode RO (a) Pemeriksaan komponen, (b) Pemasangan pemurni air yang telah diperbaiki.

Selanjutnya, kegiatan yang melibatkan para dosen Prodi Teknik Mesin Unhan RI dalam perbaikan alat pemurni air dengan metode RO dapat dilihat pada Gambar 6. Dari pemeriksaan terhadap setiap komponen utama dari alat tersebut, seperti pada Gambar 6.(a), didapatkan bahwa terdapat kebocoran pada komponen sambungan aliran sehingga memerlukan penggantian komponen. Sambungan pada kabel listrik yang pernah diperbaiki sebelumnya juga diperbaiki lagi untuk mengurangi potensi kerusakan yang lebih fatal. Gambar 6.(b) menunjukkan aktivitas pemasangan kembali pemurni air yang telah diperbaiki. Alat pemurni air telah berhasil beroperasi kembali dengan baik di RSIA Melania Cibinong.

Penerapan keahlian Prodi Teknik Mesin Unhan RI dalam PKM ini tidak hanya terkait proses perbaikan tetapi juga melibatkan proses desain dan produksi produk yang salah satunya adalah mesin cuci tangan otomatis dengan sensor gerak inframerah. Gambar 7 menunjukkan pemasangan hasil produksi dan pengujian performa kerja mesin cuci tangan otomatis yang ditempatkan di RSIA Melania Cibinong.

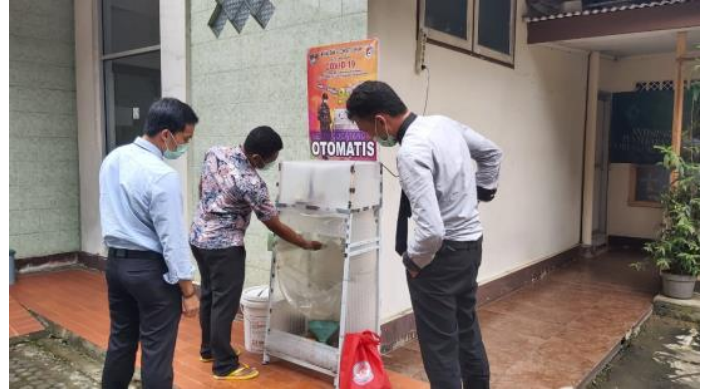

Gambar 7. Pemasangan dan pengujian mesin cuci tangan otomatis dengan sensor gerak inframerah

Sebagai puncak dari kegiatan PKM Prodi Teknik Mesin Unhan RI adalah sosialisasi Bela Negara yang dilakukan selama satu hari. Gambar 8 menunjukkan aktivitas sosialisasi Bela Negara yang dilakukan di RSIA Melania Cibinong. Pimpinan dan staf rumah sakit mengikuti acara ini dengan antusias sehingga sosialisasi dapat berjalan dengan baik. Dalam kegiatan puncak ini juga dilakukan pelatihan perawatan genset oleh dosen Prodi Teknik Mesin kepada karyawan rumah sakit yang akan bertugas merawat genset yang telah dapat beroperasi kembali seperti terlihat pada Gambar 9.

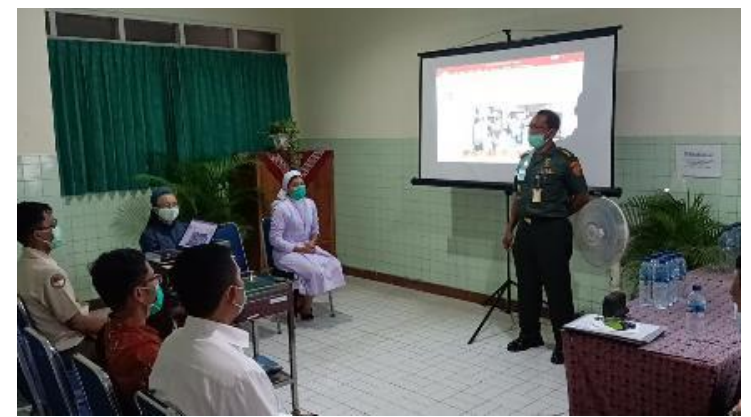

Gambar 8. Aktivitas sosialisasi Bela Negara

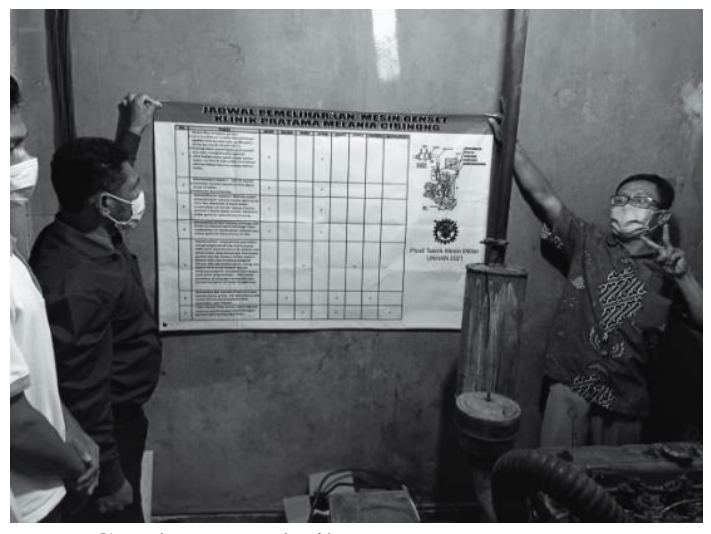

Gambar 9. Pelatihan perawatan genset 


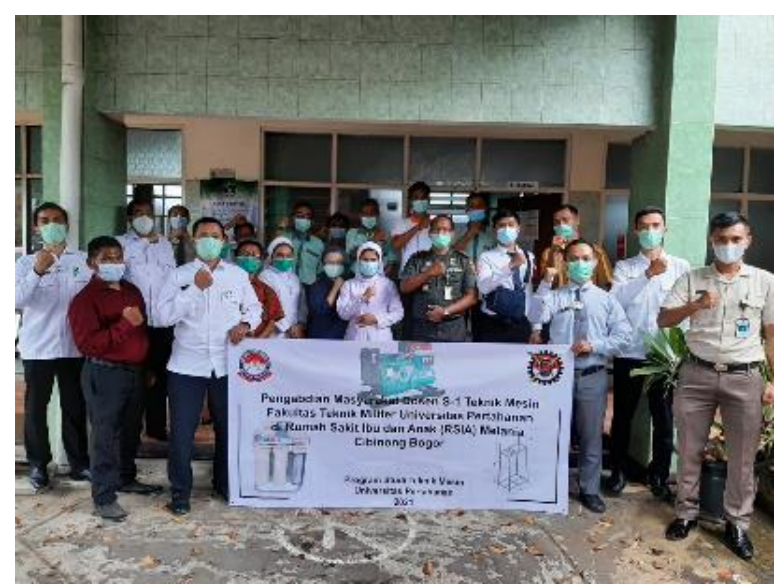

Gambar 10. Foto bersama peserta sosialisasi Bela Negara

Kegiatan sosialisasi Bela Negara ditutup dengan melakukan foto bersama, pada Gambar 10, yang diikuti semua peserta sosialisasi dalam kegiatan PKM ini. Foto bersama ini masih tetap mengikuti protokol kesehatan dengan memakai masker dan menjaga jarak. Kegiatan PKM ini telah membuka kesempatan dan ruang baru untuk penerapan keahlian Teknik Mesin dalam mendukung berbagai misi kemanusiaan bagi tenaga medis. Sinergi yang saling mendukung antara semangat bela negara dan kemanusiaan antara dua institusi dalam kegiatan PKM ini tetap diharapkan terus terjalin baik.

\section{KESIMPULAN}

Dengan terlaksananya kegiatan PKM Prodi Teknik Mesin Unhan di RSIA Melania Cibinong, maka dapat diperoleh beberapa simpulan yaitu

1. Kegiatan PKM oleh masyarakat akademis di lingkungan Prodi Teknik Mesin Unhan RI telah dilakukan sebagai pemenuhan Tri Dharma perguruan tinggi.

2. Terjadi sinergi yang saling menguatkan antara pelayanan kemanusiaan RSIA Melania Cibinong dengan pelayanan Bela Negara Prodi Teknik Mesin Unhan RI.

3. Seluruh pihak, baik dari Prodi Teknik Mesin Unhan RI maupun RSIA Melania Cibinong, terlibat aktif dalam pelaksanaan kegiatan PKM yang dilakukan.

4. Penerapan keahlian Teknik Mesin dapat mendukung keberlangsungan operasional rumah sakit dalam pelayanan kemanusiaan.

5. Kegiatan sosialisasi Bela Negara bagi pimpinan dan karyawan rumah sakit mendukung sumber daya manusia yang memiliki jiwa ksatria dan bertanggung jawab tidak hanya untuk kepentingan kemanusiaan saat bertugas di rumah sakit tetapi juga untuk bangsa dan negara.

6. Kegiatan PKM Prodi Teknik Mesin Unhan RI di RSIA Melania Cibinong menunjukkan sinergi bela negara dan kemanusiaan dalam rangka mendukung kehidupan berbangsa dan bernegara yang sehat dan humanis.

\section{UCAPAN TERIMA KASIH}

Penulis menyampaikan terima kasih untuk dukungan teknis maupun operasional terhadap pelaksanaan PKM ini. Masyarakat akademis di lingkungan Prodi Teknik Mesin:
Letkol (Cpl) Linus Yoseph Wawan Rukmono, S.T., M.T., Hadi Wahyudi, S.T., M.T., Ph.D., Dr. Edy Susanto, S.T., M.T., Dr. Arie Sukma Jaya, S.T., M.Eng., Dr. Arief Nur Pratomo S.T., M.T., Dr. Eng. Rando Tungga Dewa, S.T., M.Eng., Ariyo Nurrachman Satiya Permata, S.T., M.Eng., Aditia Aulia, S.T., M.Sc., Eka Irianto Bhiftime, S.T., M.T., Ridho Illahi Putra, S.H., Hanung Bayu Setiawan, S.T., M.Han. Pimpinan RSIA Melania Cibinong: Suster Maria Veronika SFS.

\section{REFERENSI}

[1] "Profil," 2009. https://www.idu.ac.id/profil (diakses pada Mar. 29, 2021).

[2] "Identitas," 2009. https://www.idu.ac.id/profil/identitas (diakses pada Mar. 29, 2021).

[3] H. R. P. Sinaga, "Pendidikan Bela Negara yang Diselenggarakan Pusdikif," J. Prodi Peperangan Asimetris, vol. 3, no. 3, pp. 63-80, 2017.

[4] J. Indrawan dan M. P. Aji, "Pendidikan Bela Negara Sebagai Mata Kuliah Di Perguruan Tinggi," J. Pertahanan Bela Negara, vol. 8, no. 3, pp. 1-24, 2018, doi: 10.33172/jpbh.v8i3.437.

[5] "PDDikti - Pangkalan Data Pendidikan Tinggi," 2020. https://pddikti.kemdikbud.go.id/data_prodi/NUQ0RDY 2Q0MtRUQzOS00NkY1LUExMkItQzA4OENBNUUz NUI3 (diakses pada Mar. 29, 2021).

[6] C. F. Suan, "Faktor-faktor yang berhubungan keputusan ibu primigravida menentukan tempat persalinan di RSIA Melania Cibinong", Undergraduate thesis, STIK Sint Carolus, 2016.

[7] Stetoskoop, "Tentang Rumah Sakit Ibu dan Anak Melania - Cibinong," 2021. http://stetoskoop.com/id/hospital/rumah-sakit-ibu-dananak-melania--cibinong (diakses pada Mar. 29, 2021).

[8] SehatQ, "RSIA Melania Cibinong," 2018. https://www.sehatq.com/faskes/rumah-sakit-melaniacibinong (diakses pada Mar. 29, 2021).

[9] A. Alfirman, S. Sukamto, G. Sastria dan Z. Bahri, "Perakitan dan perbaikan komputer untuk meningkatan kualitas remaja di Desa Pandau Jaya Kecamatan Siak Hulu Kabupaten Kampar”, unricsce, vol. 1, pp. 243-254, Sep. 2019.

[10] M. Y. T. Sulistyono, W. S. Sari dan I. Septriana, "Pemberdayaan Remaja Putus Sekolah dan Pengangguran Dalam Pembentukan Komunitas Wira Usaha Jasa Perbaikan Komputer dan Jaringan Komputer," sens2. 2016.

[11] A. Syaputra, "Pelatihan Maintenance Komputer Pada Himpunan Mahasiswa Teknik Informatika Kota Pagar Alam," NGABDIMAS, Vol. 3, No. 2, pp. 75-81, 2020, https://doi.org/10.36050/ngabdimas.v3i2.274.

[12] Y. Basongan dan M. Iswar. "IbM Perawatan dan Perbaikan Generator Set (Genset) di Desa Nisombalia," Seminar Nasional Hasil Penelitian \& Pengabdian Kepada Masyarakat (SNP2M), pp. 474478, 2017.

[13] K. Purwanto, S. Suripto, R. O. Wiyagi, Y. Ardiyanto dan 
M. Y. Mustar, "Implementasi Emergency Backup Pada Instalasi Listrik Di Masjid An Nuur, Gamping Tengah," dalam Prosiding Seminar Nasional Program Pengabdian Masyarakat, 2020.

[14] D. Aribowo, Desmira, and D. A. Fauzan, "Sistem Perawatan Mesin Genset di PT (Persero) Pelabuhan Indonesia II," Pros. Semin. Nas. Pendidik. FKIP, Vol. 3, No. 1, pp. 580-594, 2020.

[15] S. Teguh, "Uji Kelayakan Operasi Genset BRV20 RSGGAS Setelah dilakukan Perbaikan," dalam Prosiding Seminar Nasional Teknologi Pengelolaan Limbah XIV, pp. 268-277, 2016.

[16] L. K. Wardana, "Pengolahan Air Mineral dalam Kemasan Rendah Kontaminasi," Berdikari: Jurnal Inovasi dan Penerapan Ipteks, Vol. 6, No. 2, 162-172, 2018.

[17] D. D. Djamaluddin, M. Anshar, Z. Muslimin, R.S. Sadrat, E. Palantei, M. Baharuddin, A. D. Achmad, Wardi dan S. Syarif, "Pelatihan Trouble Shooting Sistem RO di Kecamatan Marusu Kabupaten Maros," JURNAL TEPAT: Applied Technology Journal for Community
Engagement and Services, Vol. 2, No. 2, pp. 1-6, 2019.

[18] "Reverse Osmosis (RO) Fact Sheet," 2019. [Online]. Available:

https://www.wqa.org/Portals/0/Technical/Technical Fact Sheets/2019_RO.pdf.

[19] T. H. Saputra, H. A. Pamasaria, B. Wiratmoko, R. Hermawan dan R. Supriyono, "Rancang Bangun Mesin Cuci Tangan Otomatis Portabel untuk Mengurangi Efek Pandemi Covid 19," LOGISTA-Jurnal Ilmiah Pengabdian kepada Masyarakat, Vol. 4, No. 2, pp. 534540, 2020.

[20] R. Romadhoni, B. Santoso dan M. Helmi, "Pembuatan Alat Cuci Tangan Mobile Dalam Pencegahan Corona Virus pada Tempat Ibadah," INTEGRITAS: Jurnal Pengabdian, Vol. 4, No. 2, pp. 264-274, 2020.

[21] L. Y. W. Rukmono, A. S. Jaya, A. Aulia, and E. I. Bhiftime, "Rancang bangun mesin cuci tangan otomatis cutato-Unhan berbasis karakteristik anthropometri," dalam Prosiding Seminar Nasional Ilmu Teknik dan Aplikasi Industri (SINTA), Vol. 3, 2020. 